\title{
Simulation Model for Optimal Operation of Dokan Dam Reservoir Northern of Iraq
}

\author{
Sadeq Oleiwi Sulaiman ${ }^{1}$, Hasan Hussein Abdullah², Nadhir Al-Ansari ${ }^{3 *}$, Jan Laue ${ }^{3}$, Zaher Mundher Yaseen ${ }^{4}$ \\ ${ }^{1}$ Dams and Water Resources Engineering, College of Engineering, University of Anbar, Ramadi 31001, Iraq \\ ${ }^{2}$ Ministry of Water Resources, Baghdad 10001, Iraq \\ ${ }^{3}$ Civil, Environmental and Natural Resources Engineering, Lulea University of Technology, Lulea 97187, Sweden \\ ${ }^{4}$ New Era and Development in Civil Engineering Research Group, Scientific Research Center, Al-Ayen University, Thi-Qar \\ 64001, Iraq
}

Corresponding Author Email: nadhir.alansari@ltu.se

https://doi.org/10.18280/ijdne.160308

Received: 22 April 2021

Accepted: 11 June 2021

\section{Keywords:}

HEC-ResSim 3.0, Dokan Dam, reservoir simulation, optimal operation model, Iraq

\begin{abstract}
Due to the limitation of water renewable resources on one hand and increasing growth in consuming water in different parts such as agriculture, industry, urban, and the environment in other hand, face management of these valuable resources to many challenges. Present study attempts to clarify recent condition of the problem and introduce effective management tools in water supply sector. In order to achieve this purpose, simulating model HEC-Res Sim was used for Dokan Dam to study the operational behavior of the reservoir and to investigate the model capability in representing and simulating the real system. The study based on monthly discharge data for the period from 1986 to 2016 measured at the inlet of Dokan Dam reservoir. The results of the current study were compared and evaluated against those counterparts observed data using two statistical metrics, correlation coefficient and Nash- Sutcliff coefficient efficiency. Moreover, an empirical formula was found linking the amount of inflow to the reservoir with the amount of outflow. The results showed that the HECResSim 3.0 performed well in simulating the monthly discharges. Therefore, HECResSim 3.0 could be used for better water system analysis in this study area.
\end{abstract}

\section{INTRODUCTION}

Hydrological qualifications are the primary drivers of repository the board and straightforwardly influence the operational options provided because of its variable and dubious structure [1]. A viable store the board and its methodologies ought to be founded on the hydrological reaction and the present circumstance of the framework [2], [3]. Appropriate activity of water assets stays on the motivation of administrative foundations and privately owned businesses who manage multi-target the board considering water equipping, water allotment and flooding issues [4]. The executives of repository frameworks from intending to activity is extremely testing since the issue manages many entangled factors and vulnerabilities, for example, inflows, return streams, stockpiles, redirections, entomb/intra-bowl water moves, water system, and mechanical as well as city water supply requests $[5,6]$. An ideal arrangement mostly comprises contradictory choices due to the supply framework guidelines plans. A repository framework guideline plan, working strategy, or discharge approach are of utmost important principles in deciding the amounts of water to be put away or discharged or pulled back from a supply [7, 8], or arrangement of a few repositories, under different conditions [9-11]. The principal issue is to choose how much water must be put away and additionally discharged, particularly for moderately little stores, without making any water deficiency in the long haul because of crisis conditions in the midst of flood.

Hydrologic Engineering Centre's Reservoir System
Simulation (HEC-ResSim) is specific programming to recreate water assets frameworks discharged in 2003 by US Army Corps of Engineers (USACE) rather than (HEC-5) bundle, and the changed adaptation discharge (HEC-ResSim 3.0) was in April 2007 [12]. This model has an enormous capacity of recreating repositories frameworks and supports the viable choices making to work and supply various necessities, similar to flood moderation, hydroelectric control age, water system, water supply also, securing nature through the utilization distinctive operational approaches. This model incorporates three separate arrangements of capacities called (Modules), and through each set an assortment of framework information is entered, and each set incorporates a rundown of devices and extraordinary directions [13].

Tică et al. [14] Utilized (HEC-ResSim 3.1) model to rebuild stores framework situated in Vidraru hydropower, and the point was to upgrade the comprehension of the power generation plan over a year and to choose the best choices for the administration of flow that could be put resources into the generation of hydroelectric power. Wondye [15] examined the Blue Nile River Basin (Abay) in Ethiopia and assembled a recreation model utilizing (HEC-ResSim 3.0) model to reenact the dispersion of water and utilize it for water system and hydroelectric power age. HEC-ResSim with another softwires where used to make a reservoir model and simulated the process of rainfall-runoff with hydropower generation. They showed that the catchment of the dam under study will generally become warmer and wetter with a more increase in annual precipitation in the near than the far future [16]. An 
assessment of the climate change impact on the Kulekhani Hydropower Project (KHP) in Nepal was made to maximize hydropower generation under climate change scenarios and evaluate the adaptation options, were a hydrological models used to simulate future discharge and hydropower generation under climate change scenarios [17]. An analysis of water balance for a system consists of three reservoirs on Nam Ngum River basin near Vientiane, Laos PDR was carried out using the HEC-ResSim 3.0. The Operational management of multiple reservoirs and hydropower plants for available water was optimized to maximize the power generation [18]. A base up approach is a partner driven procedure to survey helplessness instead of a dependence on prescient models of things to come. Three basic water assets segments were chosen for assessment: flood chance administration, environments, and farming. Job of Dniester waterway repositories: balance requirement for putting away rising waters with the requirement for water equipping through drought periods [19]. Provides a detailed outline of the procedure proposed to finish a Hydrologic and Project Operations Model as a major aspect of the Parr and Fairfield relicensing venture. These models utilized for survey capacity to give potential changes to extend activities, and the subsequent impacts of potential adjustments to tasks of the undertakings. Lara et al. [20] presented a direct contextual investigation utilizing the HEC-ResSim model of the Tucurui Dam's repository, situated in the territory of Para, Brazil. The hydrological investigation was performed to comprehend the operational imperatives of the repository. The operational principles were assessed by the attributes of the repository capacity, the stream limit of the spillways and the stream limit of the waterway waste downstream of the Tucurui Dam. Likewise, there was discourse how to coordinate the device in a continuous estimate framework.

HEC-ResSim 3.0 package was used to simulate the Mosul dam reservoir in the north of Iraq, the reservoir operation behaviours were studied based on monthly data and the results showed it is very convenient in simulating the real system through testing and comparing the model results with historically recorded data [21]. Based on the reported literatures $[22,23]$, there is a serious matter related to the water resources management and particularly in the Iraq region, and thus this research was inspired to build a simulation model for Dokan Dam reservoir to study the operation behaviours of the reservoir and the hydropower generation using HEC-ResSim 3.0 package. To the best of the knowledge, very few studies addressed this model capability in Iraq. Results obtained using this model was compared with the observed data at the reservoir inlet.

\section{DESCRIPTION OF THE STUDY AREA}

Dokan Dam is situated on the Lesser Zab tributary around $295 \mathrm{~km}$ north of Baghdad and $65 \mathrm{~km}$ southeast of Sulaimaniyah city (Figure 1). The dam is a concrete arch with gravity projection squares situated in a tight steep sided gorge etched in the limestone and dolomite bedrock. The peak length of the dam is $350 \mathrm{~m}$ and has a greatest length of $116 \mathrm{~m}$. The supply seized by Dokan Dam had an all-out structure limit at ordinary working stage (El. 511.00 m.a.s.l) of 6,870 Million $\mathrm{m}^{3}$, of which 6,140 Million $\mathrm{m}^{3}$ is live stockpiling and 730 Million $\mathrm{m}^{3}$ being dead stockpiling. The present stockpiles will be not as much as this due to more than 45 years of sedimentation i.e. almost $1 \mathrm{~mm} / \mathrm{km}^{2}$ per year of fine material.
The reservoir storage is constrained by two spillways, both situated on left bank of the reservoir. The spillway, which is gated, has three vertical entryways, with $10 \mathrm{~m}$ high by $6.8 \mathrm{~m}$ wide. The water outflow release into a short steep chute interfacing with a $11 \mathrm{~m}$ breadth burrow with a free outlet set about 50 m over the stream in the canyon estuary of the dam.

The discharges can be made through two water system outlets that are supported by a passage going underneath the dam on the correct bank. This passage is subdivided underneath the top of the dam, where each $2.29 \mathrm{~m}$ distance across steel lined passages closed by emergency gates lowered from the dam crest. Every one of these passages associates with a steel channel with a butterfly control sluice and stream is directed by an empty fly release sluice with a greatest limit of $120 \mathrm{~m}^{3} / \mathrm{s}$ each at full supply stage [24].

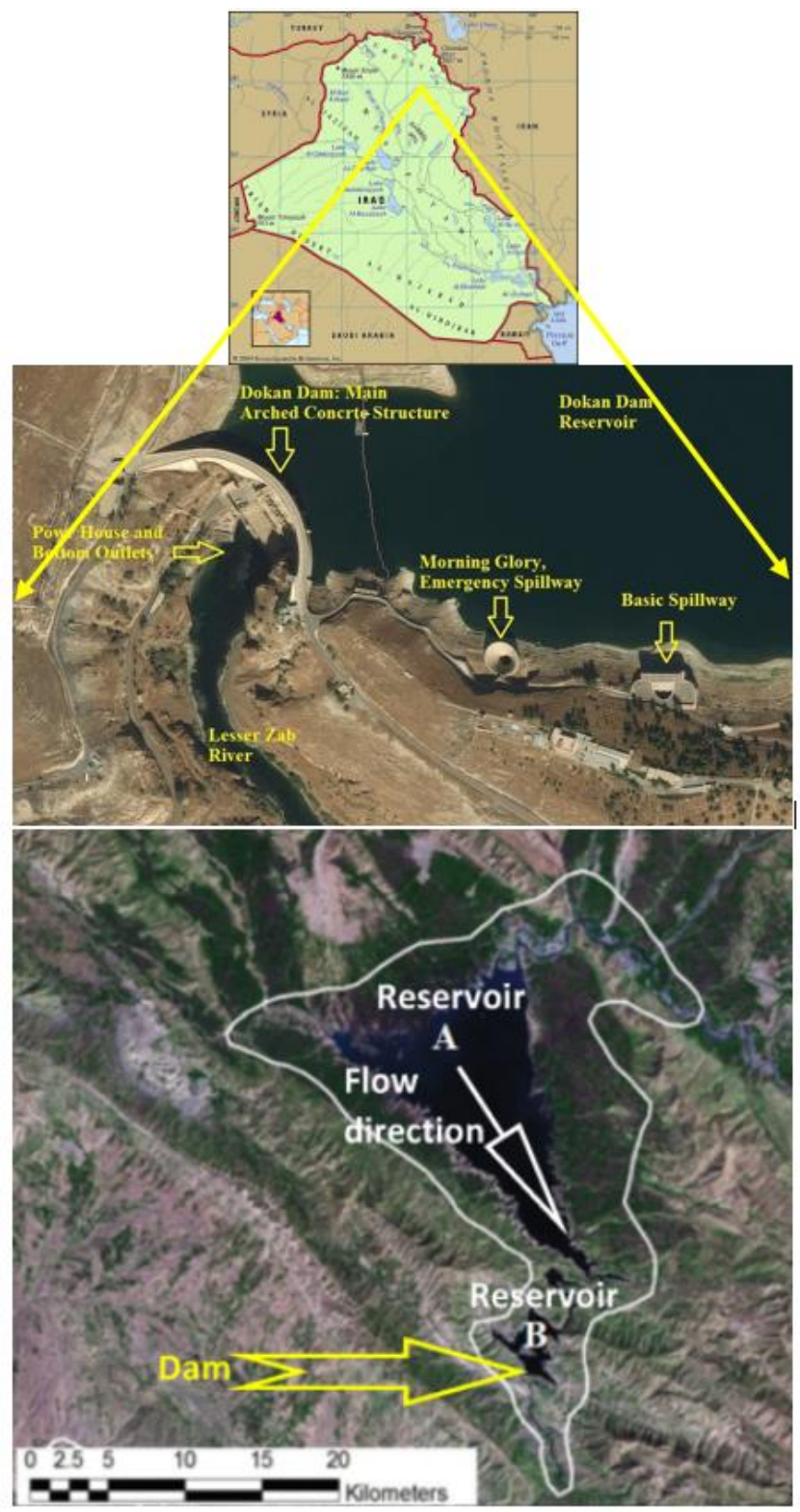

Figure 1. The location of Dokan Dam and reservoir

\section{MATERIALS AND METHODS}

A simulation model was constructed fundamentally using observed monthly data of inflows from the Lesser Zab tributary to the reservoir. Moreover, the depth of rainfall on 
the surface area of the lake and the depth of evaporation from the surface area of the lake were also collected, to fulfill the water requirements downstream with the constraints of the highest and lowest release from the reservoir that has been taken from previous studies. Different hydrological conditions were considered during the model operation. A number of important variables are included within the model input to improve model performance. Various data such as knowledge of physical characteristics, operating rules, and hydropower generation features such as gate power curves, inputting actual values of power plant efficiency, hydraulic losses, and backwater difference are required when construction of the reservoir nodes during hydraulic modeling. Monthly water requirement was taken into consideration for various irrigation sites, domestic and industrial water supply, and hydroelectric generation requirements. The calculation was done by using the index-sequential method in different time periods to reproduce historical inflow patterns. The data from 1986 to 2016 was used as time series input data. Figure 2 shows the elevation-area-storage curves of the reservoir. Figure 3 shows the hydraulic losses of the hydroelectric power plant for the reservoir. Figure 4 shows the average monthly evaporation from the reservoir's surface area for the period from 1986 to 2016.

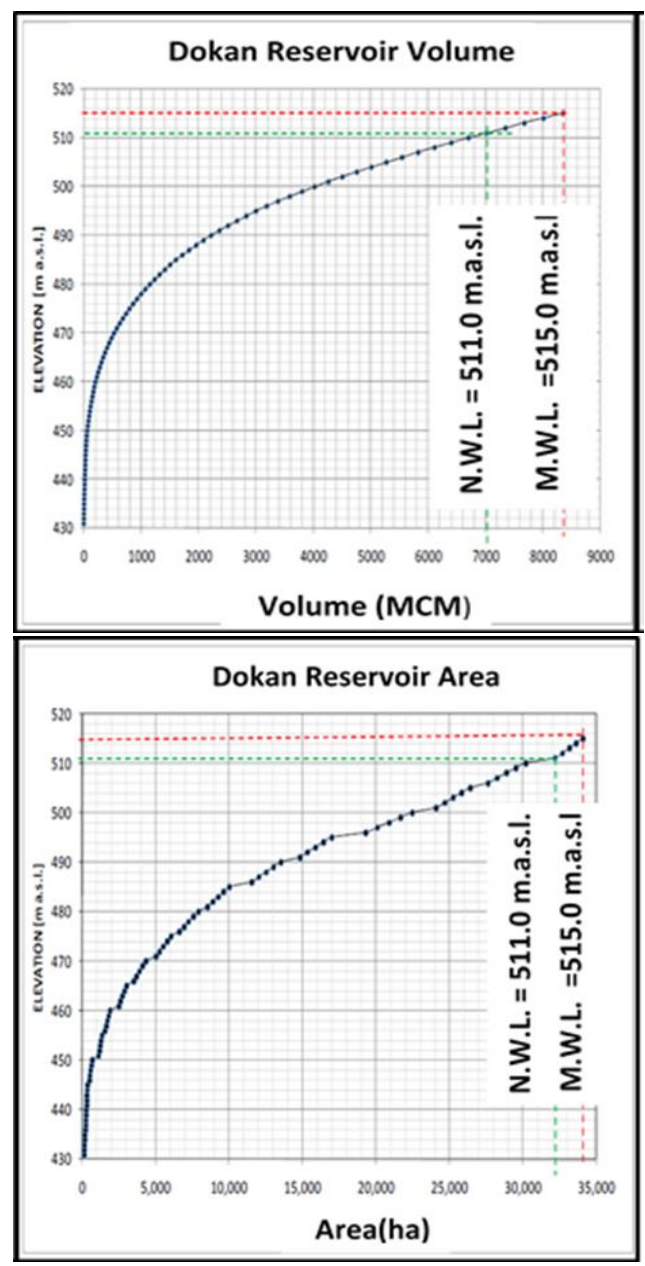

Figure 2. The elevation - area - storage curves of Dokan Dam reservoir

The simulation was carried out for 360 months of the period from January 1986 to December 2016 on the monthly basis. The constructed model was delineated as shown in Figure 5. Its performance was evaluated against the observed data using two statistical metrics (i.e. correlation coefficient and NashSutcliff coefficient efficiency). The observed monthly data included the reservoir discharges and hydroelectric vitality produced for the whole reproduction. In addition, the observed month to month of supply release were acquired for the time of the study.

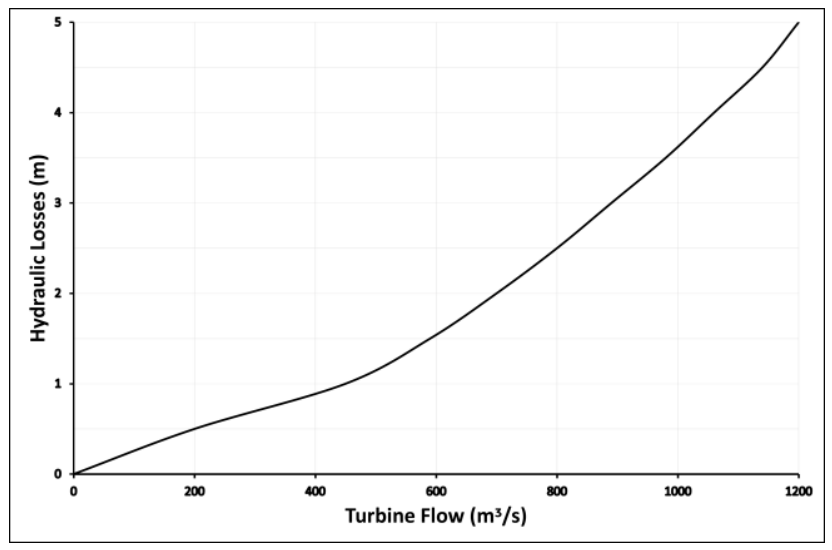

Figure 3. Hydraulic losses of hydroelectric power plant from Dokan Dam reservoir

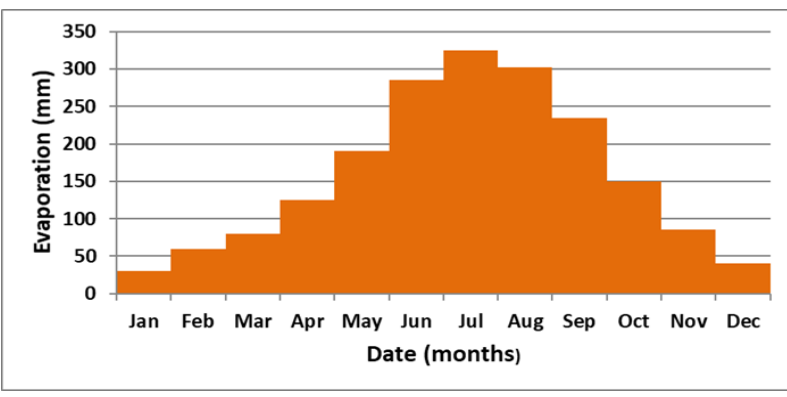

Figure 4. Average monthly evaporation from the reservoir's surface area

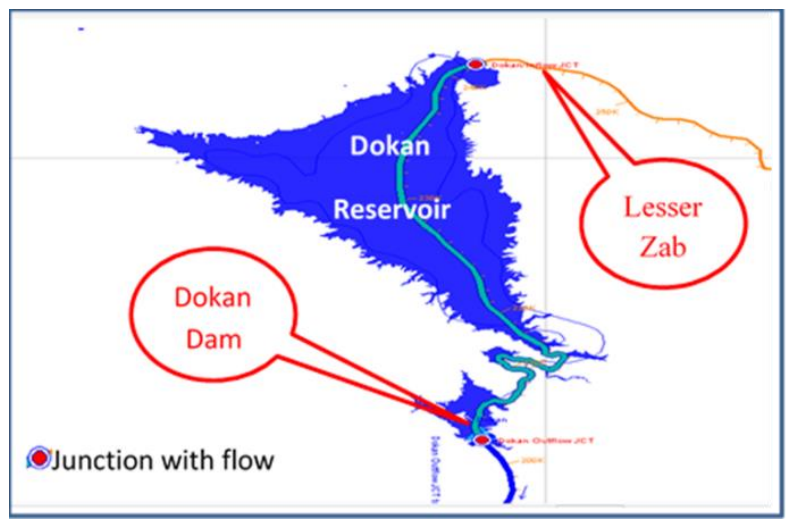

Figure 5. Simulation model of Dokan Dam Reservoir in HEC-ResSim 3.0 package

\section{MODEL ASSESSMENT}

Two statistical metrics were used to evaluate the model performances which are:

i. Correlation coefficient (r)

Which is a measure of the degree of linear correlation between two indented variables, and its value lies between (1) and (-1). It can be estimated using the following equation [25]. 


$$
r=\frac{\sum_{i=1}^{n}\left(O_{i}-O^{-}\right) \cdot\left(S_{i}-S^{-}\right)}{\sqrt{\sum_{i=1}^{n}\left(O_{i}-O^{-}\right)^{2} \cdot \sum_{i=1}^{n}\left(S_{i}-S^{-}\right)^{2}}}
$$

where, $O_{i}$ is the observed values in the period $i . S_{i}$ is the simulated values in the period $i . O^{-}$is the average of the observed values. $S^{-}$is the average of simulated values. $n$ is the number of values.

\section{ii. Nash-sutcliff coefficient efficiency (NSCE)}

This method is used to describe the predictive accuracy of the model when there are observed data. It is used to evaluate the foretells proficiency of the hydrological models. The efficiency of Nash-Sutcliffe coefficient is calculated by subtracting the number 1 of the disparity ratio error in the calculated time series divided by the measured time series variation. In the case of an ideal model with an error estimation disproportion equal to zero, the Nash-Sutcliffe coefficient efficiency is equal to 1 . On the contrary, the model that generates a valuation error deviation equal to the deviation of the calculated time series results in a Nash-Sutcliffe model efficiency coefficient of 0 . The amount of the NSCE that closer to 1 refers to that the model having the proficiency of predicting events of observed time series results. The NashSutcliffe model efficiency coefficient is defined as [26, 27]:

$$
N S C E=1-\left[\frac{\sum_{i=1}^{n}\left(O_{i}-S_{i}\right)^{2}}{\sum_{i=1}^{n}\left(O_{i}-O^{-}\right)^{2}}\right]
$$

\section{RESULTS AND DISCUSSION}

Through the simulation process, the storage volume, surface area and elevation were calculated as shown in Figure 6. Also, the Inflow and outflow from reservoir were calculated with the storage, as shown in Figure 7.

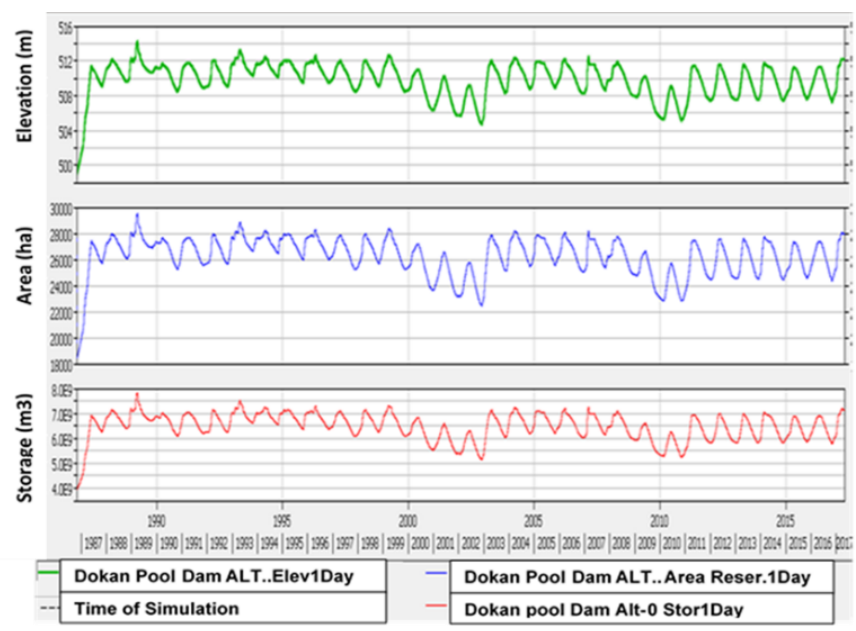

Figure 6. Elevation- area- storage curves of Dokan reservoir during the simulation period

The realization of the model is examined after calibration using measured inflows, outflows, and water levels at the Dokan Dam reservoir for historical data from 1986 to 2016. The convergence of the current model with the observed data for the actual operation of the reservoir for the releases was tested by comparing the recorded values of the releases with the values calculated from the model using the Correlation Coefficient and the efficiency coefficient as their value reached 0.97 and as shown in Figure 8. It can be seen that there is a noticeable convergence between the measured values for releases from the reservoir and the values obtained from the model.

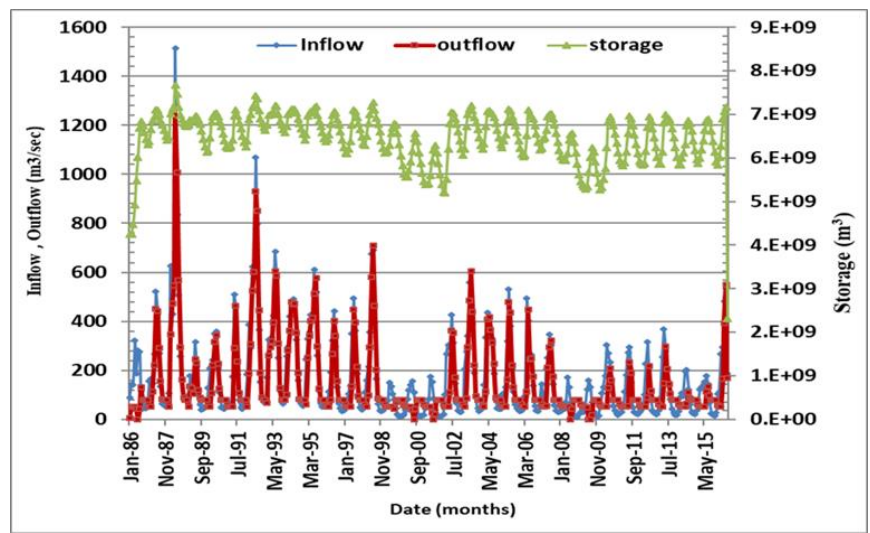

Figure 7. The Inflow, outflow and storage from Dokan reservoir

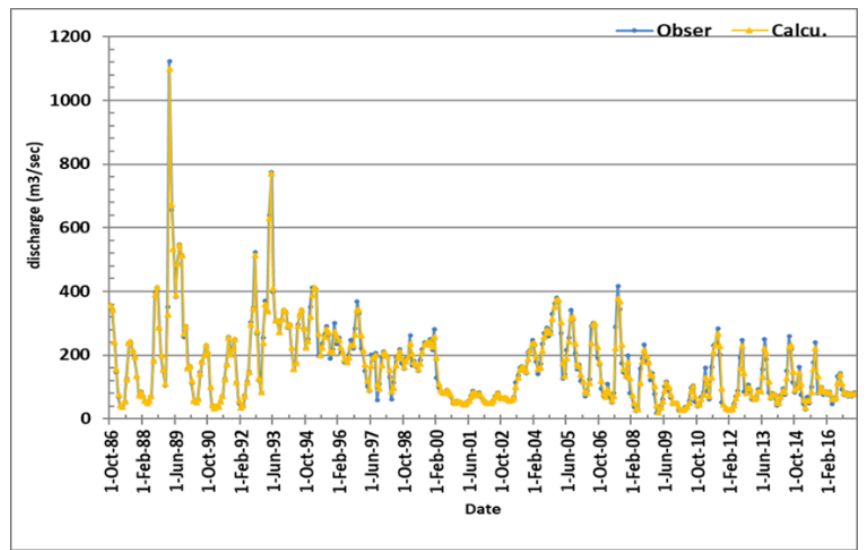

Figure 8. The measured release and the calculated values from the model for Dokan reservoir

The behaviour of the dam reservoir operation was also evaluated due to the amount of change in inflow and outflow from the reservoir of dam and the consequent changes in the size of the reservoir where a consistent relationship was found between those variables during the period of increase and decrease. The correlation coefficient was calculated between the outflow and the inflow of the reservoir, where it reached the limits of 0.9. Also, the best formula was found linking these variables as shown below.

$$
\begin{aligned}
\text { OUT }=a(I N F)^{5} & +b(I N F)^{4}+c(I N F)^{3}+d(I N F)^{2} \\
& +e(I N F)+f
\end{aligned}
$$

where, OUT is the outflow from Dokan reservoir $\left(\mathrm{m}^{3} / \mathrm{sec}\right), I N F$ is inflow to Dokan reservoir $\left(\mathrm{m}^{3} / \mathrm{sec}\right)$, coefficient of Multiple Determination $\quad\left(\mathrm{R}^{2}\right)=0.9, \quad \mathrm{a}=-1.08043726512315 \mathrm{E}-12$, $\mathrm{b}=4.71171728398552 \mathrm{E}-09, \quad \mathrm{c}=-7.74996517465839 \mathrm{E}-06$, $\mathrm{d}=5.63941308968765 \mathrm{E}-03, \quad \mathrm{e}=-0.666906285242921$, $\mathrm{f}=88.3713398437577$.

\section{CONCLUSIONS}

An implemented successfully and efficiently simulation of 
the Dokan Dam Reservoir using the HEC-Res-Sim 3.0 model which is used in simulating water resource systems. In this study, the model was examined by comparing its results with the observed data. The data matching was good and proved to be a very effective model for representing the real system. Moreover, a mathematical equation was found to calculate the amount of water released from the dam, based on the amount of water coming into the reservoir. It was also observed that there was a great match between the amount of water released from the tank calculated from the model with and observed and a significant correlation was observed between the area and volume curves of the reservoir with the water level in the reservoir.

\section{ACKNOWLEDGMENT}

We appreciate the reviewers' comments for enhancing the content of the manuscript.

\section{REFERENCES}

[1] Perea, R.G., Moreno, M.Á., da Silva Baptista, V.B., Córcoles, J.I. (2020). Decision support system based on genetic algorithms to optimize the daily management of water abstraction from multiple groundwater supply sources. Water Resources Management, 34(15): 47394755. https://doi.org/10.1007/s11269-020-02687-1

[2] Yaseen, Z.M., Ehteram, M., Hossain, M., Fai, C.M., Binti Koting, S., Mohd, N.S., El-Shafie, A. (2019). A novel hybrid evolutionary data-intelligence algorithm for irrigation and power production management: application to multi-purpose reservoir systems. Sustainability, $11(7)$ : 1953 https://doi.org/10.3390/su11071953

[3] Najm, A.B.A., Abdulhameed, I.M., Sulaiman, S.O. (2020). Water requirements of crops under various Kc coefficient approaches by using water evaluation and planning (WEAP). International Journal of Design \& Nature and Ecodynamics, 15(5): 739-748. https://doi.org/10.18280/ijdne.150516

[4] Sulaiman, S.O., Al-Ansari, N., Shahadha, A., Ismaeel, R., Mohammad, S. (2021). Evaluation of sediment transport empirical equations: case study of the Euphrates River West Iraq. Arabian Journal of Geosciences, 14(10): 1-11. https://doi.org/10.1007/s12517-021-07177-1

[5] Rani, D., Moreira, M.M. (2010). Simulationoptimization modeling: A survey and potential application in reservoir systems operation. Water Resources Management, 24(6): 1107-1138. https://doi.org/10.1007/s11269-009-9488-0

[6] Sulaiman, S.O., Kamel, A.H., Sayl, K.N., Alfadhel, M.Y. (2019). Water resources management and sustainability over the Western desert of Iraq. Environmental Earth Sciences, 78(16): 1-15. https://doi.org/10.1007/s12665019-8510-y

[7] Awadh, S.M., Al-Mimar, H., Yaseen, Z.M. (2020). Groundwater availability and water demand sustainability over the upper mega aquifers of Arabian Peninsula and west region of Iraq. Environment, Development and Sustainability, pp. 1-21. https://doi.org/10.1007/s10668-019-00578-z

[8] Noon, A.M., Ahmed, H.G.I., Sulaiman, S.O. (2021).
Assessment of Water Demand in Al-Anbar ProvinceIraq. Environ. Ecol. Res., 9(2): 64-75. https://doi.org/10.13189/eer.2021.090203

[9] Wurbs, R.A. (1993). Reservoir-system simulation and optimization models. Journal of Water Resources Planning and Management, 119(4): 455-472. https://doi.org/10.1061/(ASCE)07339496(1993)119:4(455)

[10] Sulaiman, S.O., Al-Dulaimi, G., Al Thamiry, H. (2018). Natural rivers longitudinal dispersion coefficient simulation using hybrid soft computing model. In 2018 11th International Conference on Developments in eSystems Engineering (DeSE), pp. 280-283. https://doi.org/10.1109/DeSE.2018.00056

[11] Islam, M.S., Sadiq, R., Rodriguez, M.J., Najjaran, H., Hoorfar, M. (2016). Integrated decision support system for prognostic and diagnostic analyses of water distribution system failures. Water Resources Management, 30(8): 2831-2850. https://doi.org/10.1007/s11269-016-1326-6

[12] Choi, Y., Ahn, J., Ji, J., Lee, E., Yi, J. (2020). Effects of inter-basin water transfer project operation for emergency water supply. Water Resources Management, 34: 2535-2548. https://doi.org/10.1007\%2Fs11269-02002574-9

[13] Klipsch, J.D., Hurst, M.B. (2013). HEC-ResSim Reservoir System Simulation User's Manual Version 3.1. CPD-82: 556.

[14] Tică, E.I., Ahmad-Rashid, K., Sima, O.V., Pisău, D.M., Coman, A.R., Popa, B. (2020). HEC-ResSim Optimization Model on Vidraru Hydropower Development.

[15] Wondye, F. (2009). Abay Basin Water Allocation Modelling Using Hec - Ressim. M.Sc. Thesis, Civil Eng. Dept., Addis Ababa University, Ethiopia.

[16] Beheshti, M., Heidari, A., Saghafian, B. (2019). Susceptibility of hydropower generation to climate change: Karun III Dam case study. Water, 11(5): 1025. https://doi.org/10.3390/w11051025

[17] Shrestha, A., Shrestha, S., Tingsanchali, T., Budhathoki, A., Ninsawat, S. (2021). Adapting hydropower production to climate change: A case study of Kulekhani Hydropower Project in Nepal. Journal of Cleaner Production, $\quad 279$ : 123483. https://doi.org/10.1016/j.jclepro.2020.123483

[18] Sorachampa, P., Tippayawong, N., Ngamsanroaj, K. (2020). Optimizing multiple reservoir system operation for maximum hydroelectric power generation. Energy Reports, 6: $67-75$. https://doi.org/10.1016/j.egyr.2019.11.043

[19] Kleinschmidt. (2014). Final Study Plan Hydraulic \& Project Operations Model. parr hydroelectric project FERC No. 1894, Prepared for: South Carolina Electric \& Gas Company, Cayce, South Carolina.

[20] Lara, P.G., Lopes, J.D., Luz, G.M., Bonuma, N.B. (2014). Reservoir operation employing HEC-ResSim: Case study of Tucuruí dam, Brazil.

[21] Jebbo, B.E., Awchi, T.A. (2016). Simulation model for Mosul dam reservoir using HEC-ResSim 3.0 package. ZANCO Journal of Pure and Applied Sciences, 28(2): 92-98. https://doi.org/10.21271/ZJPAS.V28I2.547

[22] Hamidi, M. (2020). The key role of water resources management in the Middle East dust events. Catena, 187: 104337. https://doi.org/10.1016/j.catena.2019.104337 
[23] Ahmad, H.Q., Kamaruddin, S.A., Agha, O., Mahmood, M.A., Harun, S.B., Zaaboul, R. (2020). A review of meteorological drought based indices towards integrated water resources management in Iraq. Journal of Computational and Theoretical Nanoscience, 17(2-3): 663-672. https://doi.org/10.1166/jctn.2020.8816

[24] SMEC. (2006). Dokan and Derbendikhan Dam Inspections. Project number: 5062018; Report for: World Bank.

[25] Olsson, U., Drasgow, F., Dorans, N.J. (1982). The polyserial correlation coefficient. Psychometrika, 47(3): 337-347. https://doi.org/10.1007\%2FBF02294164

[26] Yan, B., Guo, S., Liang, J., Sun, H. (2015). The generalized Nash model for river flow routing. Journal of Hydrology, 530:

79-86. https://doi.org/10.1016/j.jhydrol.2015.09.055

[27] Nash, J.E., Sutcliffe, J.V. (1970). River flow forecasting through conceptual models part I-A discussion of principles. Journal of Hydrology, 10(3): 282-290. https://doi.org/10.1016/0022-1694(70)90255-6 